\title{
Erfaringer med helsevesenet blant foreldre til barn med Downs syndrom
}

\author{
ORIGINALARTIKKEL
}

\section{MARTE JOHANNE STEFFERUD}

Faculty of Health Sciences

University of Troms $\emptyset$ - The Arctic University of Norway

She has contributed to the idea, design of the questionnaire, data collection, analysis and interpretation, literature searches, drafting and revision of the manuscript and approval of the submitted manuscript version.

Marte Johanne Stefferud, medical student.

The author has completed the ICMJE form and declares no conflicts of interest.

\section{ANNE GRETHE EINANG}

Hedmark Habilitation Service Section of Paediatrics

Innlandet Hospital Trust

She has contributed to the design of the questionnaire, data collection and interpretation, and approval of the submitted manuscript version.

Anne Grethe Einang, special-needs educator, head of section and former board member of the Norwegian Network for Down Syndrome (NNDS).

The author has completed the ICMJE form and declares no conflicts of interest.

\section{CLAUS KLINGENBERG}

claus.klingenberg@unn.no

Department of Paediatrics University Hospital of North Norway

and

Department of Clinical Medicine

Faculty of Health Sciences

UiT The Arctic University of Norway

Author contribution: study design, data analysis and interpretation, revision and finalisation of the manuscript, and approval of the submitted version.

Claus Klingenberg, specialist in paediatrics, senior consultant/head of section, and professor.

The author has completed the ICMJE form and declares no conflicts of interest.

\section{BAKGRUNN}

Barn og ungdom med Downs syndrom har et stort behov for oppfølging i primær- og spesialisthelsetjenesten. 
Vi publiserte i juni 2019 et spørreskjema på Norsk Nettverk for Down syndrom sin Facebook-gruppe. Formålet var å undersøke brukererfaringer med helsevesenet blant foreldre til barn og ungdom ( $\mathrm{o}-20$ år) med Downs syndrom.

\section{RESULTATER}

Vi fikk 174 svar. Mest fornøyd var foreldre med oppfølgingen av tilleggsdiagnoser som synsproblemer, hjertefeil og stoffskiftesykdom. Minst fornøyd var foreldrene til barn med problemer knyttet til adferd, søvn og pubertet. Omtrent 6 av 10 foreldre rapporterte ingen negative opplevelser med helsevesenet, men 29/161 (18\%) rapporterte at diagnosen Downs syndrom hadde bidratt til behandlingssvikt hos barnelege eller i barnehabiliteringstjenesten.

\section{FORTOLKNING}

Studien indikerer at det både i primær- og spesialisthelsetjenesten er behov for bedre oppfølging av barn og unge med Downs syndrom.

\section{HOVEDFUNN}

I en spørreundersøkelse blant 174 foreldre til barn med Downs syndrom hadde rundt 6 av 10 foreldre ingen negative erfaringer med helsevesenet.

Foreldre var mest fornøyd med oppfølging av synsproblemer, hjertefeil og stoffskiftet, og minst fornøyd med oppfølgingen av psykiatriske utfordringer samt problemer knyttet til søvn og pubertet.

$18 \%$ av foreldrene rapporterte at de hadde opplevd behandlingssvikt hos barnelege eller i barnehabiliteringstjenesten.

Downs syndrom er den vanligste enkeltstående årsak til utviklingshemming i Norge (11). De siste 20 årene har det i Norge årlig blitt født 60 - go barn med Downs syndrom (므). Mennesker med Downs syndrom har komplekse medisinske og sosiale behov. Foreldre til barn med funksjonshemminger opplever utfordringer med å få riktig medisinsk støtte og hjelp. Mange arbeider redusert for å følge opp barnet $(3,4$.). For å øke barnets og foreldrenes psykiske og fysiske helse er god kontakt mellom brukere og de som leverer helsetjenester viktig. Vi har gjort en spørreundersøkelse blant foreldre til barn og ungdom med Downs syndrom. Formålet med studien var å undersøke deres erfaringer i møte med ulike deler av helsevesenet, med fokus på oppfølgingsrutiner og eventuelle negative opplevelser.

\section{Materiale og metode}

Vi utarbeidet et eget spørreskjema da vi ikke fant validerte skjema som tematisk dekket målene med studien. I juni 2019 la vi ut spørreskjemaet (se appendiks på tidsskriftet.no) som en internettbasert lenke for medlemmene i Norsk Nettverk for Down syndrom sin Facebook-gruppe. Gruppen har rundt 4500 medlemmer, inkludert personer med Downs syndrom, deres familie/foresatte og fagpersonell. Vi la senere ut tre påminnelser før spørreskjemaet ble lukket i oktober 2019.

Spørreskjemaet hadde 18 spørsmål med ett eller flere svaralternativer, samt mulighet for fritekstbesvarelse. Første del omhandlet bakgrunnsinformasjon om barnet, inkludert tilleggsdiagnoser. Andre del fokuserte på foreldrenes møte med helsevesenet, og hvordan de oppfattet oppfølgingen av barnet. Svaralternativene ble presentert i en fem-delt Likertskala. Den siste delen av spørreskjemaet ga informasjon om hvilken forelder som svarte og i 
hvilken helseregion familien bodde. Fritekstbesvarelser ble ikke systematisk analysert, men benyttet for å belyse tema som ikke kom frem i tilstrekkelig grad i spørsmål med faste svaralternativ.

\section{STATISTISKE ANALYSER}

Data ble overført til SPSS. Hovedfunn er beskrevet deskriptivt. Sammenligning mellom grupper ble gjort med kji-kvadrat-test. $\mathrm{P}<0,05$ ble vurdert som signifikant.

ETIKK OG PERSONVERN

I henhold til meldeskjema, Norsk senter for forskningsdata konkluderte vi med at data ikke kunne brukes til personidentifikasjon (5). Studien ble vurdert som ikke fremleggingspliktig av Regionale komite for medisinsk og helsefaglig forskningsetikk.

\section{Resultater}

174 foreldre med barn i alder o - 20 år besvarte første del av spørreskjemaet, 161 (93\%) andre del og 157 (90 \%) tredje del. Det var flest mødre (143/157; 91\%) som svarte. Tabell 1 viser at $117 / 174(67 \%)$ av barna var yngre enn 10 år og at 130/174 (75\%) hadde en eller flere tilleggsdiagnoser, hyppigst hjertefeil.

\section{Tabell 1}

Bakgrunnsinformasjon om 174 barn og ungdom med Downs syndrom i en spørreundersøkelse om foreldrenes erfaringer i møte med helsevesenet.

\begin{tabular}{|c|c|}
\hline Variabel & Andel \\
\hline \multicolumn{2}{|l|}{ Alder } \\
\hline $0-3$ & $45(25,9 \%)$ \\
\hline $4-6$ & $36(20,7 \%)$ \\
\hline $7-9$ & $36(20,7 \%)$ \\
\hline $10-12$ & $24(13,8 \%)$ \\
\hline $13-17$ & $25(14,4 \%)$ \\
\hline $18-20$ & $8(4,6 \%)$ \\
\hline \multicolumn{2}{|l|}{ Vanligste tilleggsdiagnoser } \\
\hline Hjertefeil & $61(35,1 \%)$ \\
\hline Øre-nese-hals sykdommer & $49(28,2 \%)$ \\
\hline Mage-tarm sykdommer & $44(25,3 \%))$ \\
\hline Stoffskiftesykdom & $37(21,1 \%)$ \\
\hline Obstruktiv søvnapnesyndrom & $27(15,5 \%)$ \\
\hline Autisme & $7(4,0 \%)$ \\
\hline Epilepsi & $8(4,6 \%)$ \\
\hline
\end{tabular}

Tabell 2 viser at foreldrene var mest fornøyd med oppfølgingen av tilstander som synsproblemer, hjertefeil og stoffskiftet. Elleve foreldre kommenterte imidlertid i fritekst at de selv måtte følge opp og etterspørre rutinekontroller. Høyest andel misnøye med 
oppfølgingen i helsevesenet fant vi ved oppfølgingen av psykiatriske utfordringer, problemer med søvn og rundt pubertet (tabell 2). Åtte foreldre nevnte i fritekst at det var for dårlig kunnskapsnivå på sammenhengen mellom helseplager og atferdsforstyrrelser. Flere foreldre (110/161; $68 \%$ ) var fornøyd med oppfølgingen hos fastlege eller annen legespesialist enn med oppfølging hos barnelege/barnehabiliteringstjenesten (87/161; 54\%), $\mathrm{p}=\mathrm{o}, 008$. Foreldrene var mer fornøyd med kunnskapsnivået hos barnelege/barnehabiliteringstjenesten (112/161; 69\%) enn hos fastlege (57/161; 35\%), p < o,oo1. Foreldrene til barn uten tilleggsdiagnoser var mer fornøyd med oppfølgingen hos fastlege (32/39; $82 \%$ ) enn foreldrene til barn med tilleggsdiagnoser (78/122;64\%), p = o,034. Det framkom i fritekst at tre av foreldrene ikke hadde hørt om barnehabiliteringstjenesten, og ytterligere seks hadde vanskeligheter med å få hjelp fra tjenesten. Ti foreldre rapportere i fritekst om mangel på samhandling og koordinasjon mellom ulike helsetjenester.

\section{Tabell 2}

Tilfredshet blant foreldre til barn og ungdom med Downs syndrom med oppfølgingen i helsevesenet av ulike mulige tilleggsdiagnoser/problemstillinger. De tre tilstandene med høyest og lavest skår er vist med fet skrifttype.

\begin{tabular}{|c|c|c|c|c|}
\hline Diagnosegruppe & $\begin{array}{l}\text { Veldig bra eller } \\
\text { bra }\end{array}$ & Nøytral & $\begin{array}{l}\text { Veldig dårlig eller } \\
\text { dårlig }\end{array}$ & Total, $\mathrm{n}^{1}$ \\
\hline Søvn & $29(30,5 \%)$ & $24(25,3 \%)$ & $42(44,2 \%)$ & 95 \\
\hline Pubertet & $5(15,2 \%)$ & $16(48,5 \%)$ & $12(36,4 \%)$ & 33 \\
\hline Mage-tarm & 38 (37,3 \%) & $28(27,5 \%)$ & 36 (35,3 \%) & 102 \\
\hline Øre-nese hals & $91(60,7 \%)$ & $34(22,7 \%)$ & 25 (16,7 \%) & 150 \\
\hline Psykiatri & $3(6,7 \%)$ & 15 (33,3 \%) & $27(60,0 \%)$ & 45 \\
\hline Epilepsi & $7(41,2 \%)$ & 9 (52,9\%) & $1(5,9 \%)$ & 17 \\
\hline Hjerte & 90 (90,9 \%) & 9 (9,1 \%) & 0 (0 \%) & 99 \\
\hline Stoffskifte & 73 (63,5 \%) & $27(23,5 \%)$ & 15 (13,0\%) & 115 \\
\hline Kreft & $12(60,0 \%)$ & $4(20,0 \%)$ & $4(20,0 \%)$ & 20 \\
\hline Syn & $122(78,7 \%)$ & $23(14,8 \%)$ & $10(6,5 \%)$ & 155 \\
\hline
\end{tabular}

${ }^{1}$ Det var 161 foreldre totalt som besvarte denne delen av skjemaet, men totaltallet i høyre kolonne er avhengig av om foreldrene hadde opplevd at deres barn hadde fått oppfølging fra helsevesenet på det området det ble spurt om eller ikke. Noen hadde også fått oppfølging uten at det var påvist sykdom, derav høyere tall enn i Tabell 1 for noen tilstander.

Mange foreldre rapporterte at de ikke hadde hatt negative opplevelser i møte med fastlege (95/161; $59 \%$ ) eller barnelege/barnehabiliteringstjenesten (105/161; 65\%). Imidlertid rapporterte 29/161 (18\%) foreldre at diagnosen Downs syndrom hadde bidratt til behandlingssvikt hos barnelege eller i barnehabiliteringstjenesten. Ni foreldre kommenterte at deres verste opplevelse var når barnet ble født og hvordan holdningene var på fødeavdelingen.

\section{Diskusjon}


Den psykologiske belastningen i familier til barn med Downs syndrom er kjent fra tidligere (6), men ingen nordiske studier har undersøkt foreldrenes brukertilfredshet med helsevesenet. Godt over halvparten av foreldrene anga tilfredshet med oppfølging av deres barn både i primær- og spesialisthelsetjenesten, men studien avdekket forbedringsområder.

Personer med utviklingshemming har overhyppighet av tilleggsdiagnoser. I tråd med tidligere studier opplevde foreldre i vår studie det som belastende at de selv måtte ta ansvar for oppfølging av kontroller $(3,4$.). Atten prosent av foreldrene rapporterte at de hadde opplevd «behandlingssvikt», hyppigst i spesialist-helsetjenesten. Det er viktig at alt helsepersonell som følger opp personer med Downs syndrom har kunnskap om oppfølging av potensielt alvorlige tilleggsdiagnoser (7.).

Foreldrene var minst fornøyd med oppfølging av problemstillinger rundt søvn, adferd/psykiatri og pubertet. Slike problemer oppstår hos noe eldre barn med Downs syndrom og det er mindre avklart hvilke instanser i helsetjenesten som kan bistå. Det kan være årsak til mer usikkerhet og lavere tilfredshet, og antyder behov for økt kompetanse rundt adferds- og psykiske problemer hos personer med utviklingshemming ( $\underline{8})$. Primærhelsetjenesten har en viktig rolle i oppfølgingen av personer med Downs syndrom. Vår studie indikerer at god lokal oppfølging verdsettes av foreldre. Det var overraskende at noen foreldre ikke hadde hørt om eller hadde vansker med å få kontakt med barnehabiliteringstjenesten som skal koordinere tjenester og påse at regelmessig oppfølging gjennomføres $(\underline{1}, \underline{8})$.

Flere kommenterte at det var en krevende situasjon da de fikk informasjon om diagnosen Downs syndrom på fødeavdelingen. Dette er kjent også fra tidligere (9.). Det finnes gode anbefalinger om hvordan helsepersonell bør formidle informasjon ved genetiske sykdommer som Downs syndrom (므).

Denne studien har begrensninger. Vi vet ikke hvor mange foreldre til barn med Downs syndrom som er medlem av Facebook-gruppen. Vi fikk svar fra over 16o, men er usikre på om det er et representativt utvalg. Det er dermed risiko for seleksjonsbias.

Tilleggsdiagnosene var ikke nøye spesifisert, og det er mulig at noen spørsmål ble oppfattet ulikt. Forekomsten av hjertefeil, epilepsi og stoffskifteproblemer var imidlertid på linje med det som rapporteres ved Downs syndrom (11). Hos de yngste barna i studien kan adferds- og psykiske problemer ennå ikke være oppstått eller diagnostisert. Over 90 \% av de som besvarte spørreundersøkelsen var mødre og svarene kunne vært annerledes hvis flere fedre hadde svart.

\section{Konklusjon}

Selv om mange foreldre er fornøyd indikerer studien at det er behov for enda bedre oppfølging av barn og unge med Downs syndrom, både i primær- og spesialisthelsetjenesten.

Vi takker alle foreldrene som tok seg tid til å delta i denne studien.

\section{LITTERATUR}

1. Retningslinje for oppfølgning av barn og unge med Down syndrom. Regionsenter for habiliteringstjenesten for barn og unge. Oslo: Helse Sør-Øst, 2017. https://oslouniversitetssykehus.no/seksjon/regionsenter-for-habiliteringstjenesten-for-barn-og-ungerhabu/Documents/Retningslinje Down Syndrom versjon 030217.pdf Lest 6.6.2021. 
2. Folkehelseinstituttet. Medisinsk fødselsregister. http://statistikkbank.fhi.no/mfr/ Lest 6.6.2021.

3. Hedov G, Wikblad K, Annerén G. Sickness absence in Swedish parents of children with Down's syndrome: relation to self-perceived health, stress and sense of coherence. J Intellect Disabil Res 20o6; 50: 546-52. [PubMed][CrossRef]

4. Marshall J, Tanner JP, Kozyr YA et al. Services and supports for young children with Down syndrome: parent and provider perspectives. Child Care Health Dev 2015; 41:365-73. [PubMed] [CrossRef]

5. Norsk senter for forskningsdata. Meldeskjema for behandling av personopplysninger. https://meldeskjema.nsd.no/test/ Lest 5.6.2021.

6. Bourke J, Ricciardo B, Bebbington A et al. Physical and mental health in mothers of children with Down syndrome. J Pediatr 2008; 153:320-6. [PubMed][CrossRef]

7. O'Leary L, Hughes-McCormack L, Dunn K et al. Early death and causes of death of people with Down syndrome: A systematic review. J Appl Res Intellect Disabil 2018; 31: 687-708. [PubMed][CrossRef]

8. Helseoppfølging av personer med utviklingshemming. Trondheim: Nasjonalt kompetansemiljø om utviklingshemming, 2007. https:|/naku.no/kunnskapsbanken/helseoppf\%C3\%B8lging-avpersoner-med-utviklingshemming-rapport Lest 5.6.2021.

9. Skotko B. Mothers of children with Down syndrome reflect on their postnatal support. Pediatrics 2005; 115: 64-77. [PubMed][CrossRef]

10. Skotko BG, Capone GT, Kishnani PS. Postnatal diagnosis of Down syndrome: synthesis of the evidence on how best to deliver the news. Pediatrics 2009; 124: e751-8. [PubMed][CrossRef]

11. Akhtar F, Bokhari SRA. Down Syndrome. StatPearls Publishing LLC, 2021.

https://www.ncbi.nlm.nih.gov/books/NBK526016/ Lest 5.6.2021.

Publisert: 21. september 2021. Tidsskr Nor Legeforen. DOI:10.4045/tidsskr.21.0024

Mottatt 9.1.2021, første revisjon innsendt 3.5.2021, godkjent 5.7.2021.

Publisert under åpen tilgang CC BY-ND. Lastet ned fra tidsskriftet.no 26. april 2023. 